Article

\title{
Toxin Profiles of Okadaic Acid Analogues and Other Lipophilic Toxins in Dinophysis from Japanese Coastal Waters
}

\author{
Hajime Uchida ${ }^{1}$, Ryuichi Watanabe ${ }^{1}$, Ryoji Matsushima ${ }^{1}$, Hiroshi Oikawa ${ }^{1}$, Satoshi Nagai ${ }^{1}$, \\ Takashi Kamiyama ${ }^{2}$, Katsuhisa Baba ${ }^{3}$, Akira Miyazono ${ }^{4}$, Yuki Kosaka ${ }^{5}$, Shinnosuke Kaga ${ }^{6}$, \\ Yukihiko Matsuyama ${ }^{7}$ and Toshiyuki Suzuki ${ }^{1, *}$ \\ 1 National Research Institute of Fisheries Science, Japan Fisheries Research and Education Agency, 2-12-4 \\ Fukuura, Kanazawa-ku, Yokohama, Kanagawa 236-8648, Japan; huchida@affrc.go.jp (H.U.); \\ rwatanabe@affrc.go.jp (R.W.); matsur@affrc.go.jp (R.M.); oikawah@affrc.go.jp (H.O.); \\ snagai@affrc.go.jp (S.N.) \\ 2 National Research Institute of Fisheries and Environment of Inland Sea, Japan Fisheries Research and \\ Education Agency, 2-17-5, Maruishi, Hatsukaichi, Hiroshima 739-0452, Japan; kamiyama@affrc.go.jp \\ 3 Central Fisheries Research Institute, Fisheries Research Department, Hokkaido Research Organization, 238, \\ Hamanakacho, Yoichi-cho, Yoichi-gun, Hokkaido 046-8555, Japan; baba-katuhisa@hro.or.jp \\ 4 Kushiro Fisheries Research Institute, Fisheries Research Department, Hokkaido Research Organization, 4-25, \\ Nakahamacho, Kushiro-city, Hokkaido 085-0027, Japan; miyazono-akira@hro.or.jp \\ 5 Aomori Prefectural Industrial Technology Research Center, Fisheries Research Institute, Hiranai, \\ Higashitsugarugun, Aomori 039-3381, Japan; yuuki_kosaka@aomori-itc.or.jp \\ 6 Iwate Fisheries Technology Center, 3-75-3 Hirata, Kamaishi, Iwate 026-0001, Japan; s-kaga@pref.iwate.jp \\ 7 Seikai National Fisheries Research Institute, Japan Fisheries Research and Education Agency, 1551-8, \\ Taira-machi, Nagasaki-shi, Nagasaki 851-2213, Japan; yukihiko@affrc.go.jp \\ * Correspondence: tsuzuki@affrc.go.jp; Tel.: +81-45-788-7662; Fax: +81-45-788-5001
}

Received: 23 September 2018; Accepted: 4 November 2018; Published: 6 November 2018

check for updates

\begin{abstract}
The identification and quantification of okadaic acid (OA)/dinophysistoxin (DTX) analogues and pectenotoxins (PTXs) in Dinophysis samples collected from coastal locations around Japan were evaluated by liquid chromatography mass spectrometry. The species identified and analyzed included Dinophysis fortii, D. acuminata, D. mitra (Phalacroma mitra), D. norvegica, D. infundibulus, D. tripos, D. caudata, D. rotundata (Phalacroma rotundatum), and D. rudgei. The dominant toxin found in $D$. acuminata was PTX2 although some samples contained DTX1 as a minor toxin. D. acuminata specimens isolated from the southwestern regions (Takada and Hiroshima) showed characteristic toxin profiles, with only OA detected in samples collected from Takada. In contrast, both OA and DTX1, in addition to a larger proportion of PTX2, were detected in D. acuminata from Hiroshima. D. fortii showed a toxin profile dominated by PTX2 although this species had higher levels of DTX1 than D. acuminata. OA was detected as a minor toxin in some D. fortii samples collected from Yakumo, Noheji, and Hakata. PTX2 was also the dominant toxin found among other Dinophysis species analyzed, such as D. norvegica, $D$. tripos, and D. caudata, although some pooled picked cells of these species contained trace levels of OA or DTX1. The results obtained in this study re-confirm that cellular toxin content and profiles are different even among strains of the same species.
\end{abstract}

Keywords: Dinophysis; diarrhetic shellfish poisoning; marine toxins; pectenotoxin; okadaic acid; dinophysistoxin

Key Contribution: Pooled picked cells of Dinophysis species collected from locations around Japan were analyzed by liquid chromatography mass spectrometry to determine their toxin content and relative toxin profiles. 


\section{Introduction}

The diarrhetic shellfish toxins (DSTs), okadaic acid (OA) and dinophysistoxins (DTXs), as well as pectenotoxins (PTXs) (Figure 1) [1], are produced by planktonic species of the genus, Dinophysis and benthic species of Prorocentrum [2]. Bivalves become contaminated with these marine toxins by feeding on toxic Dinophysis species. The regulation of DSTs recommended by Codex Alimentarius [3] is $160 \mathrm{ng}$ OA equivalent/g in the edible part of bivalves. The regulation in the European Union (EU) is a total of $160 \mathrm{ng}$ OA/DTX and PTXs/g in the edible part of bivalves [4]. The cellular toxin content and profiles of several Dinophysis species have been reported by analyzing field multispecific samples obtained by plankton net hauls, or monospecific cultures [5-18]. However, it remains important to update toxin content and profile information of Dinophysis species to improve the prediction of bivalve contamination. The cellular toxin content and profiles of Dinophysis species of pooled picked cells reported in previous studies was revised (Table 1) [19-35]. Analysis of individually picked cells was historically the only unambiguous way to ascribe a toxin profile and content information to a Dinophysis species, until 2006, when cultures of D. acuminata became available [36]. Because the cellular toxin content and profiles are different even among samples of the same species [36,37], it is necessary to clarify cellular toxin contents and profiles of Dinophysis spp. present in each bivalve monitoring area.

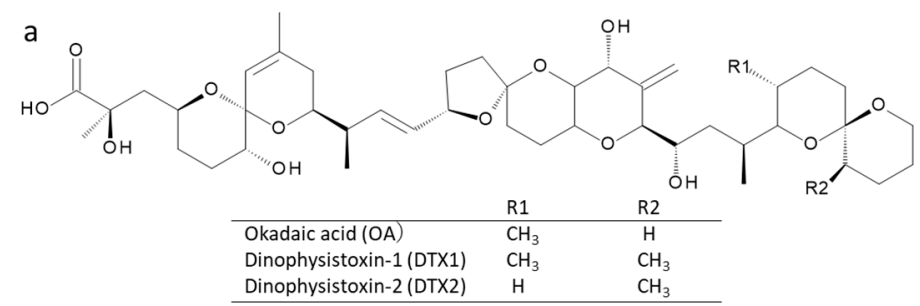

b

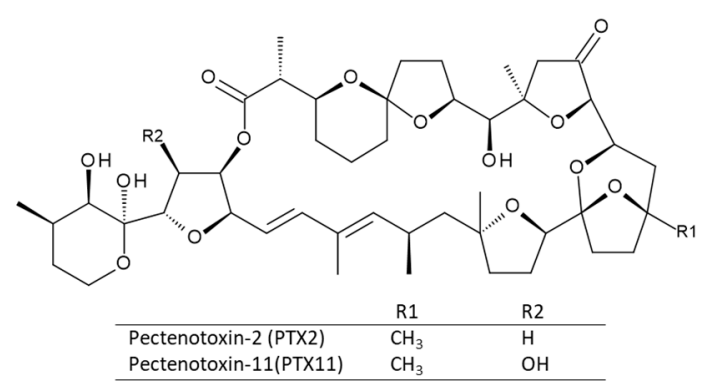

Figure 1. Chemical structure of okadaic acid (OA) and dinophysistoxin (DTX) and pectenotoxin (PTX) analogues found in Dinophysis species. (a) OA and DTX analogues. (b) PTX2 and PTX11.

Historically, DST contamination of bivalves, and associated human poisoning cases, were restricted in the northeastern regions of Japan (Tohoku and Hokkaido area). Therefore, data on the toxin content and profiles of Dinophysis from these regions is essential for predicting bivalve contamination. Although Dinophysis occurs in the southwestern parts of Japan, no toxin information has been reported for Dinophysis species found there. It is interesting that DST positive cases in bivalves obtained with the previous DST official testing method (mouse bioassay) in the southwestern parts of Japan have hardly been reported.

Between 2006 and 2014, pooled picked cells of many Dinophysis species were generated from seawater samples taken from many locations around the Japanese coastline. DSTs and PTXs were extracted using a solid phase extraction method $[6,19,23]$, and the extracts kept frozen until analysis. In this study, the presence of DSTs and PTXs in these samples was determined by liquid chromatography triple quadrupole tandem mass spectrometry (LC/MS/MS) [23] and liquid chromatography quadrupole mass spectrometry (LC/MS) [38]. 
Table 1. Reported toxin content and profiles in pooled picked cell isolates of Dinophysis field specimens.

\begin{tabular}{|c|c|c|c|c|c|c|c|}
\hline \multirow{2}{*}{ Species } & \multicolumn{4}{|c|}{ pg/cell } & \multirow{2}{*}{ Location } & \multirow{2}{*}{ Analysis Method } & \multirow{2}{*}{ Reference } \\
\hline & OA & DTX1 & DTX2 & PTX2 & & & \\
\hline \multirow[t]{8}{*}{ Dinophysis acuminata } & 1.6 & - & - & - & Le Havre, France & HPLC-FLD & [19] \\
\hline & Trace & - & - & - & Tokyo Bay, Japan & HPLC-FLD & [19] \\
\hline & 9.1 & - & - & - & Gullmar, Sweden & HPLC-FLD & [20] \\
\hline & $9.9-21.7$ & - & - & - & Galicia, Spain & HPLC-FLD & {$[21]$} \\
\hline & - & - & - & 180.0 & Bahia Inglesa, Chile & $\mathrm{LC} / \mathrm{MS} / \mathrm{MS}$ & {$[22]$} \\
\hline & - & $0.3-0.7$ & - & $10.7-22.4$ & Abashiri, Japan & LC/MS/MS & [23] \\
\hline & - & ND- 0.7 & - & $25.9-50.2$ & Yakumo, Japan & $\mathrm{LC} / \mathrm{MS} / \mathrm{MS}$ & {$[23]$} \\
\hline & 3.7 & - & - & - & Bueu, Spain & LC/MS/MS & [25] \\
\hline \multirow[t]{4}{*}{ Dinophysis fortii } & - & $13.0-191.5$ & - & 42.5 & Mutsu Bay, Japan & HPLC-FLD & [19] \\
\hline & 23.0 & - & - & - & Inland Sea, Japan & HPLC-FLD & [19] \\
\hline & ND-57.7 & ND-16.0 & - & - & Ofunato, Japan & HPLC-FLD & [26] \\
\hline & - & $8.4-10.9$ & - & $51.4-63.8$ & Yakumo, Japan & LC/MS/MS & [23] \\
\hline \multirow[t]{9}{*}{ Dinophysis acuta } & 9.4 & - & - & - & Vigo, Spain & HPLC-FLD & [19] \\
\hline & 4.0 & 4.2 & - & - & Sogndal, Norway & HPLC-FLD & [19] \\
\hline & - & 6.6 & - & - & Gullmar, Sweden & HPLC-FLD & [20] \\
\hline & $6.3-33.1$ & - & $1.0-22.0$ & - & Galicia, Spain & HPLC-FLD & [21] \\
\hline & 85.0 & - & 77.0 & 14.0 & Glandore, Ireland & $\mathrm{LC} / \mathrm{MS} / \mathrm{MS}$ & [28] \\
\hline & - & - & - & $29.1-32.3$ & Galicia, Spain & $\mathrm{LC} / \mathrm{MS} / \mathrm{MS}$ & [29] \\
\hline & $0.7-9.4$ & - & $0.9-6.6$ & $0.3-3.3$ & Pontevedra, Spain & LC/MS & [30] \\
\hline & $1.0-8.5$ & - & - & $0.2-3.3$ & Flødevigen Bay, Noway & $\mathrm{LC} / \mathrm{MS} / \mathrm{MS}$ & {$[24]$} \\
\hline & 2.9 & - & 1.9 & 1.5 & Bueu, Spain & $\mathrm{LC} / \mathrm{MS} / \mathrm{MS}$ & [25] \\
\hline \multirow[t]{5}{*}{ Dinophysis caudata } & 0.7 & - & - & - & Galicia, Spain & HPLC-FLD & [21] \\
\hline & $7.9-56.5$ & ND-53.9 & - & - & Sapian, Phillipines & HPLC-FLD & [31] \\
\hline & - & - & - & $100.0-127.4$ & Galicia, Spain & LC/MS/MS & [29] \\
\hline & 0.6 & - & 2.8 & 5.0 & Moana, Spain & $\mathrm{LC} / \mathrm{MS} / \mathrm{MS}$ & [25] \\
\hline & - & - & - & $2.0-14.5$ & Day Bay, China & $\mathrm{LC} / \mathrm{MS} / \mathrm{MS}$ & [32] \\
\hline Dinophysis infundibulus & - & - & - & 14.8 & Yakumo, Japan & $\mathrm{LC} / \mathrm{MS} / \mathrm{MS}$ & [23] \\
\hline Dinophysis miles & $5.7-20.9$ & ND-10.7 & - & - & Sapian, Phillipines & HPLC-FLD & [31] \\
\hline
\end{tabular}


Table 1. Cont.

\begin{tabular}{|c|c|c|c|c|c|c|c|}
\hline \multirow{2}{*}{ Species } & \multicolumn{4}{|c|}{ pg/cell } & \multirow{2}{*}{ Location } & \multirow{2}{*}{ Analysis Method } & \multirow{2}{*}{ Reference } \\
\hline & $\mathrm{OA}$ & DTX1 & DTX2 & PTX2 & & & \\
\hline \multirow{2}{*}{ Dinophysis mitra } & - & 10.0 & - & - & Mutsu Bay, Japan & HPLC-FLD & [19] \\
\hline & - & - & - & - & Yakumo, Japan & LC/MS/MS & [23] \\
\hline \multirow{3}{*}{ Dinophysis norvegica } & - & 14.0 & - & - & Sogndal, Norway & HPLC-FLD & [19] \\
\hline & - & - & - & $50.8-67.4$ & Yakumo, Japan & $\mathrm{LC} / \mathrm{MS} / \mathrm{MS}$ & [23] \\
\hline & ND-0.2 & - & - & $0.3-1.7$ & Flødevigen Bay, Noway & $\mathrm{LC} / \mathrm{MS} / \mathrm{MS}$ & [24] \\
\hline Dinophysis ovum & 7.1 & - & - & - & Vigo, Spain & LC/MS/MS & [33] \\
\hline \multirow[t]{4}{*}{ Dinophysis rotundata } & ND-0.4 & - & ND-0.5 & ND-0.3 & Bueu, Spain & $\mathrm{LC} / \mathrm{MS} / \mathrm{MS}$ & {$[34]$} \\
\hline & - & 101.0 & - & - & Mutsu Bay, Japan & HPLC-FLD & [19] \\
\hline & - & - & - & - & Yakumo, Japan & $\mathrm{LC} / \mathrm{MS} / \mathrm{MS}$ & [23] \\
\hline & - & - & - & 0.8 & Flødevigen Bay, Noway & $\mathrm{LC} / \mathrm{MS} / \mathrm{MS}$ & [24] \\
\hline \multirow[t]{4}{*}{ Dinophysis sacculus } & 16.5 & - & - & - & Le Croisic, France & HPLC-FLD & [35] \\
\hline & 14.0 & - & - & - & Morgat, France & HPLC-FLD & [35] \\
\hline & 29.6 & - & - & - & Kervel, France & HPLC-FLD & [35] \\
\hline & 12.9 & - & - & - & Pont-Aven, France & HPLC-FLD & [35] \\
\hline Dinophysis skagii & - & - & - & - & Bueu, Spain & LC/MS/MS & [25] \\
\hline \multirow[t]{2}{*}{ Dinophysis tripos } & - & 36.0 & - & - & Kesennuma, Japan & HPLC-FLD & [19] \\
\hline & - & - & - & - & Yakumo, Japan & $\mathrm{LC} / \mathrm{MS} / \mathrm{MS}$ & [23] \\
\hline
\end{tabular}




\section{Results}

\subsection{Dinophysis acuminata}

The toxin content and profiles of D. acuminata obtained in this study are shown in Figure 2 and Table S1. The dominant toxin in D. acuminata samples from Yakumo, Saroma, and Shimonoseki was PTX2, and DTX1 was also observed at lower levels in some samples from Yakumo and Saroma. The DTX1 content (4.7 pg/cell) found in D. acuminata sample collected in Saroma was greater than the highest value of $(0.7 \mathrm{pg} / \mathrm{cell})$ reported in previous studies (Table 1) [23]. The toxin profile and contents found from D. acuminata in Yakumo were close to those obtained in a previous study for D. acuminata in the same area [23]. It is interesting that D. acuminata collected in Uramura did not produce any of the monitored toxins. D. acuminata collected in Takada and Hiroshima showed characteristic toxin profiles, with OA exclusively detected in D. acuminata collected in Takada, whereas both OA and DTX1, in addition to a higher proportions of PTX2, were detected in D. acuminata from Hiroshima.

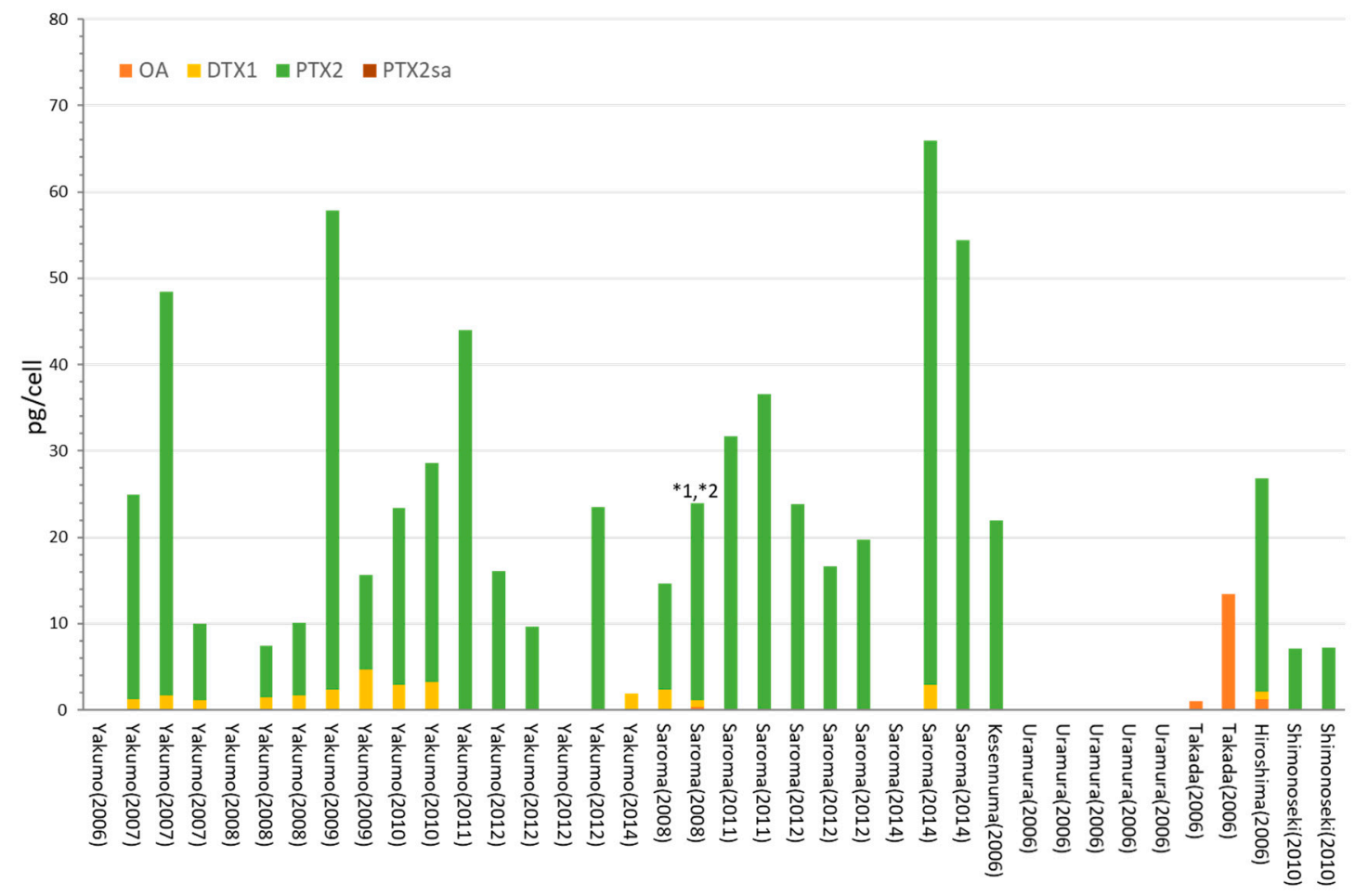

Figure 2. The toxin contents and profiles of D. acuminata in Japan. * 1 Trace levels of OA were detected. * 2 Trace levels of DTX1 were detected. The toxin contents, profiles, analyzed cell numbers, and detection limits for negative values are also given in Table S1.

\subsection{Dinophysis fortii}

The toxin content and profiles of $D$. fortii obtained in the present study are shown in Figure 3 and Table S1. Although the dominant toxin observed in D. fortii samples was PTX2, some samples also produced DTX1 or OA. The DTX1 content found in many D. fortii samples was considerably higher than that in D. acuminata. OA was detected as a minor toxin in some samples collected from Noheji and Yakumo. Several D. fortii samples from Noheji and Yakumo did not have any of the monitored toxins. PTX2 seco-acid was detected in D. fortii collected in Hakata. The PTX2 content (236.0 pg/cell) of D. fortii collected in Akita represents the highest value ever reported (Table 1) [23]. 


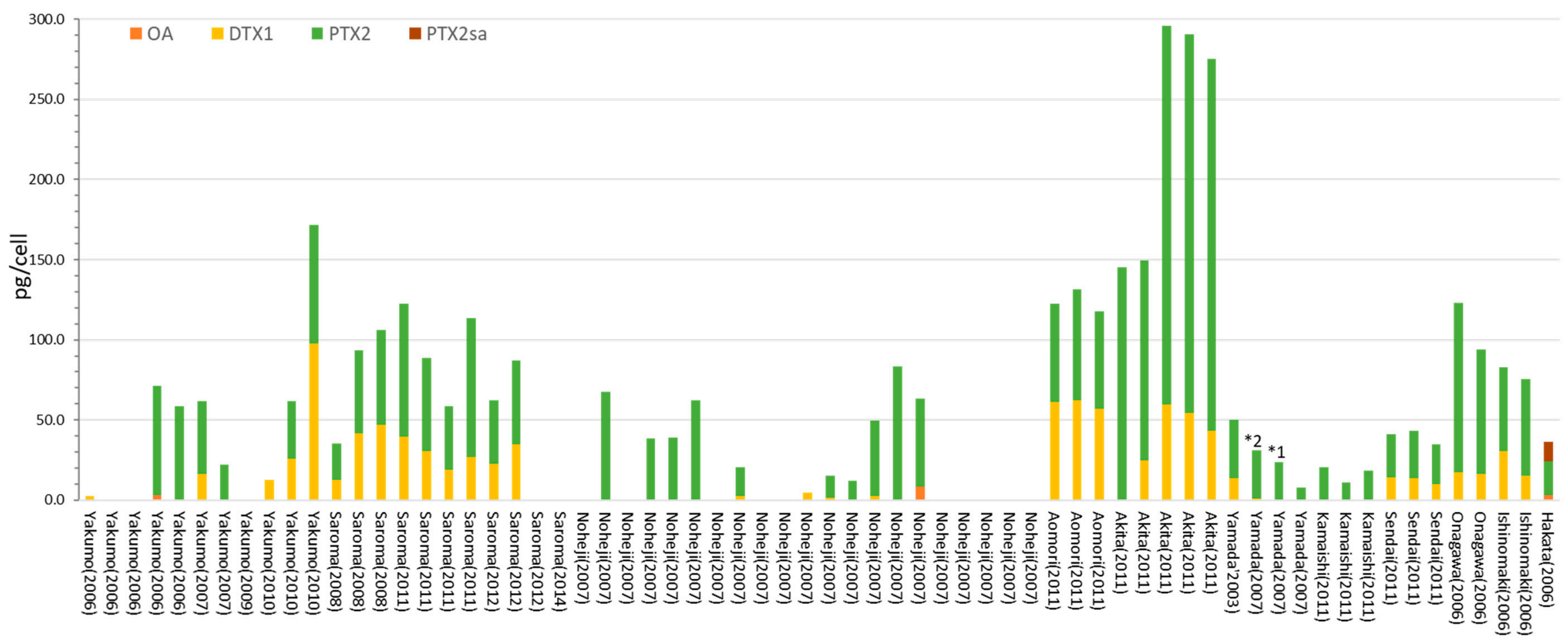

Figure 3. The toxin contents and profiles of $D$. fortii in Japan. * 1 Trace levels of OA were detected. * 2 Trace levels of DTX1 were detected. The toxin contents, the profiles, analyzed cell numbers, and detection limits for negative values are also given in Table S1. 


\subsection{Other Dinophysis Species}

PTX2 was the only toxin detected in many other Dinophysis species collected and analyzed as part of this study, including D. norvegica, D. tripos, and D. caudata. Trace levels of DTX1 or OA were observed in some of these samples (Figure 4, Table S1). PTX2 was detected for the first time in D. mitra from Yakumo (2012) by LC/MS when using selected ion monitoring (SIM) in positive ion mode. The highest PTX2 content per cell of a D. tripos found in this study was $467.4 \mathrm{pg} /$ cell, which represents the highest value ever reported (Table 1). It was also interesting that some of the other Dinophysis species collected and identified (e.g., D. rudgei) did not produce any of the monitored toxins, which aligns with the observations from D. acuminata and D. fortii isolates. Some D. mitra and D. rotundata samples, showed trace levels of DTX1 or OA. D. norvegica collected in Yakumo also contained a low level of DTX1. 


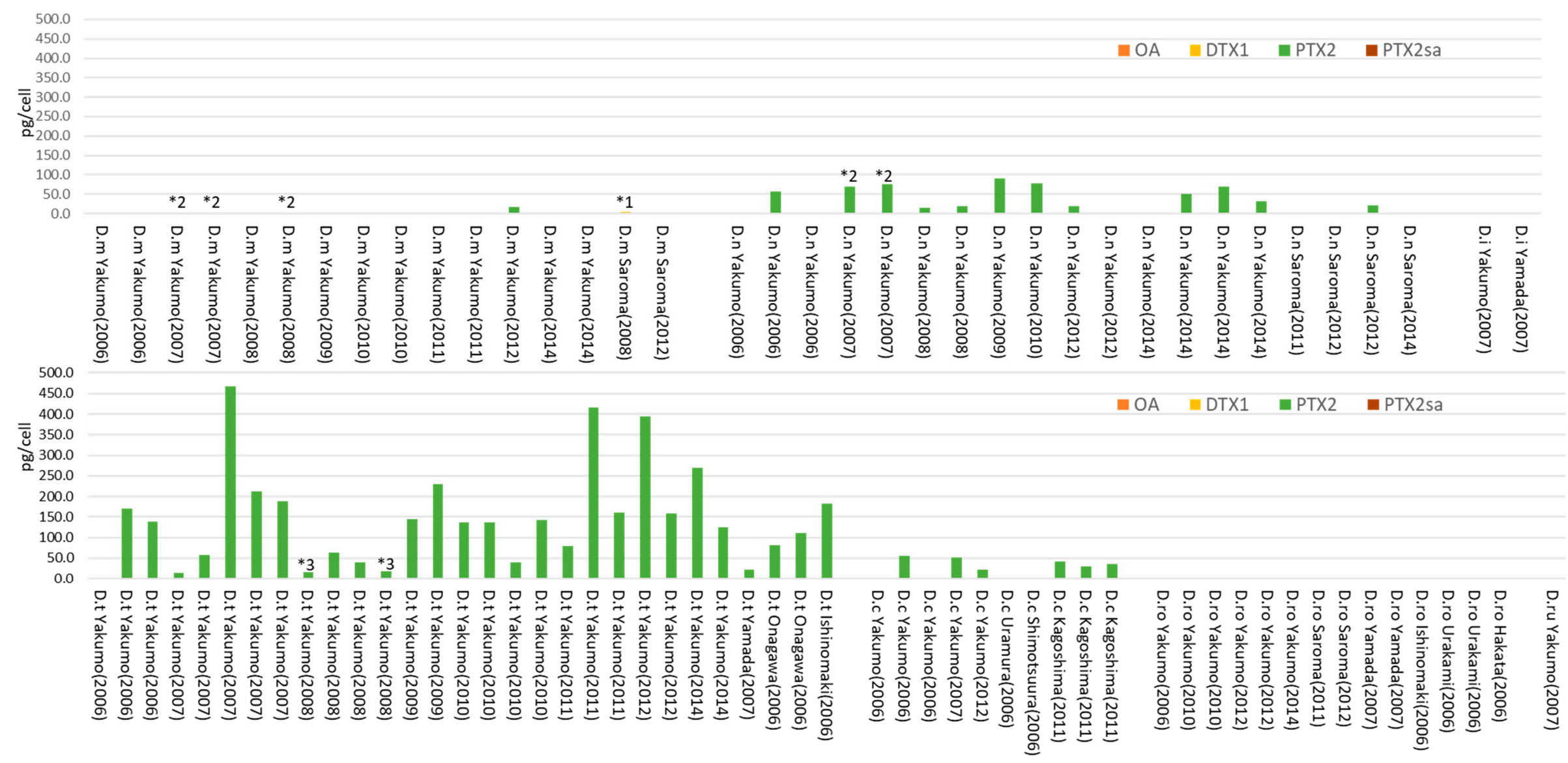

Figure 4. Toxin contents and the profiles of other Dinophysis species in Japan. D.m; D. mitra, D.n; D. norvegica, D.i; D. infundibulus, D.t; D. tripos, D.c; D. caudata, D.ro; D. rotundata, D.ru; D. rudgei. * 1 Trace levels of OA were detected. * 2 Trace levels of DTX1 were detected. * 3 Trace levels of PTX2 were detected. The toxin contents, profiles, analyzed cell numbers, and detection limits for negative values are also given in Table S1. 


\section{Discussion}

In this study, the toxin content and profiles of Dinophysis species collected around the Japanese coastline were determined. Novel findings include the detection of DTX1 in D. norvegica and PTX2 in D. caudata. OA or DTX1 have been reported in D. norvegica from coastal waters in other countries $[19,24]$. Detection of PTX2 in pooled picked cells of $D$. caudata in Japan reported for the first time, however, it has been detected in Spanish and Chinese strains of this species [25,29,32]. Detection of PTX2 in pooled picked cells of D. tripos and D. mitra is also a novel observation, although PTX2 has been detected in cultures of $D$. tripos isolated from Japan [14]. Due to the very low concentration of PTX2 observed in the D. mitra samples, its presence was not confirmed by LC/MS/MS fragment ions, and further confirmation will be required.

LC-MS analyses of picked cells of Phalacroma rotundatum (D. rotundata) showed small amounts of the same toxins (OA, DTXs, PTXs) present in the co-occurring Dinophysis species or no toxins at all. These observations led to the hypothesis that the heterotrophic P. rotundatum is not a de novo toxin-producer, but a vector of DSP toxins taken up from its tintinnid prey. [36]. The small amount of DTX1 observed in D. rotundata, and heterotroph that feedss on tintinids collected and analyzed as part of our study might be derived from DTX1 produced by other co-occurring Dinophysis species present in the area.

This study determined that the most dominant toxin produced by Dinophysis species in Japan is PTX2, except for some samples of D. acuminata, D. fortii, D. rotundata, and D. mitra that produced only OA or DTX1. PTX11, which had been detected in D. acuta from Spain and New Zealand [8,9,39], was not detected in any Dinophysis samples from Japan. This indicates that, in Japan, there is little risk of bivalves being contaminated with PTX11. It was interesting that there were non-toxic Dinophysis samples even within the same species. This demonstrates the difficulty in predicting contamination of bivalves with DSTs or PTXs by monitoring Dinophysis cell densities. Monitoring of DSTs and PTXs in plankton net samples or SPATT devices [40] by LC/MS/MS methods could be useful for early warnings of bivalve contamination with these toxins.

In Japan, the LC/MS/MS method [38] for OA/DTX analogues has been introduced as the official testing method for DSTs since 2015 [41]. In terms of early warning of bivalve contamination with DSTs, D. fortii could be regarded as the most important Dinophysis species to monitor because the DTX1 contents of $D$. fortii were relatively higher than those found in other Dinophysis species. It is interesting that sampling sites that showed DTX1-containing D. fortii coincided well with the historical human poisoning cases of DSP [42-44]. When the percentages of DTX1 and OA from D. fortii samples in Japan were compared, those of DTX1 are greater. This result is consistent with the fact that the dominant OA analogue in Japanese bivalves is DTX1 and 7-O-acyl-DTX1 [45,46]. It is also noteworthy that $D$. acuminata from Takada produces a relatively high amount of OA. Although there have been no human DSP cases in this area, attention should be payed to prevent future cases when high cell densities of $D$. acuminata were observed in this area.

Monitoring of DSP in Japanese bivalves has historically been performed using the mouse bioassay (MBA). This methodology was implemented as the official testing method for the DSP monitoring program established in the 1980s [47]. Although the presence of Dinophysis had been confirmed in southeastern regions (Tokai, Kinki, Shikoku, Sanyo, Sanin, Kyusyu regions), in Japan, there had been a few MBA positive cases in bivalves from those regions. This could be explained by the results of this study showing the dominant toxin in Dinophysis collected in the southwestern regions (Hakata, Shimonoseki, Kagoshima, Hiroshima) is PTX2, which is then converted to a MBA non-toxic PTX2SA in many bivalve species (Pacific oyster, manila clam, etc.). The exception to this is Japanese scallops, Patinopecten yessoensis (Mizuhopecten yessoensis), cultured in northeastern Japan [37,48]. However, as D. acuminata collected in Takada produces a sufficiently high amounts of OA, there is a risk of human poisoning by DSTs when there is high cell densities of D. acuminata in this region. Therefore, continuous monitoring of DSP in bivalves around the coastline of Japan is necessary. 


\section{Materials and Methods}

\subsection{Chemicals}

Okadaic acid (OA) and dinophysistoxin-1 (DTX1), pectenotoxin (PTX-1, 2, 6), and yessotoxin (YTX) were produced by the Japanese reference material project [49]. PTX-11 was isolated from D. acuta collected in New Zealand [8]. Methanol and acetonitrile, and formic acid of LC/MS grade were purchased from Kanto chemical co., Tokyo, Japan And ammonium formate of analytical grade was purchased from Nacalai tesque co., Tokyo, Japan. Distilled water was prepared by milli-Q Reference (Merck Millipore, Burlington, MA, USA).

\subsection{Sampling Locations and Dinophysis Sample Preparation}

Seawater samples were collected from various locations around the Japanese coastline (Figure 5). Using a light microscope, 50 individual cells of Dinophysis species identified in the seawater samples were carefully selected using a glass capillary to exclude non-targeted microorganisms. The cells were identified by their morphological characteristics. Isolated Dinophysis cells that had been taxonomically identified were combined in a single vessel filled with filtered seawater and stored frozen until extraction. Detailed information on the sampling is shown in Table S1.

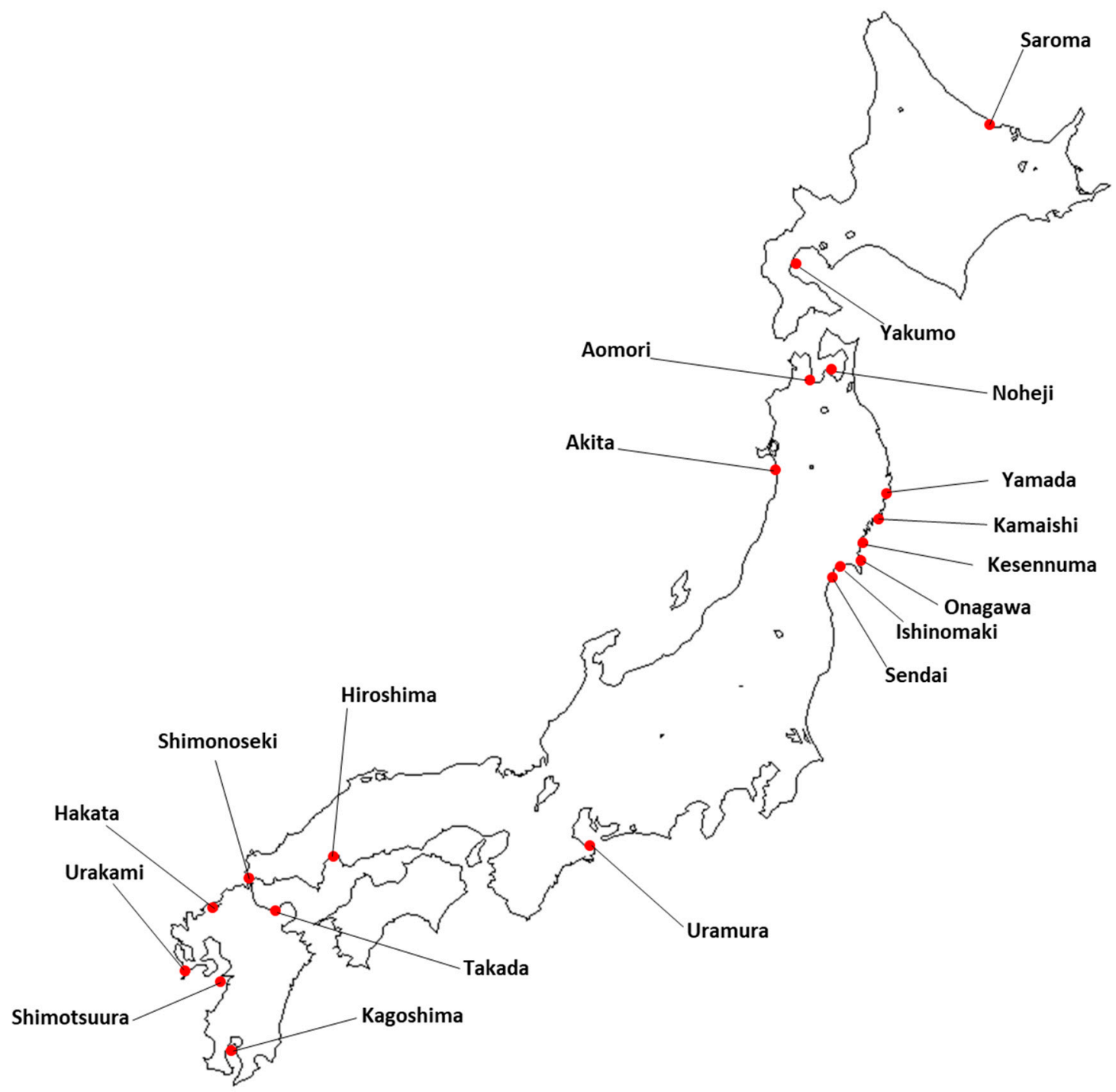

Figure 5. Dinophysis sampling locations around Japan. 


\subsection{Extraction}

Toxins were extracted from cells of Dinophysis species by solid phase extraction (SPE) (Sep pak C18 plus, Waters co., Milford, MA, USA) as reported in previous studies $[6,19,23]$. Toxin extracts were dissolved in $200 \mu \mathrm{L}$ of methanol for LC/MS/MS analysis.

\section{4. $L C / M S / M S$ and LC/MS Analysis}

LC/MS/MS analysis was carried out according to a previous method [23]. The LC/MS/MS system was an Agilent 1100 series of high performance liquid chromatograph (HPLC) (Agilent technologies, Lexington, MA, USA) coupled with a 3200 Qtrap triple quadrupole MS/MS system (Sciex, Framingham, MA, USA). Separations were performed on Quicksilver cartridge columns (50 mm $\times 2.1 \mathrm{~mm}$ i.d) packed with $3 \mu \mathrm{m}$ Hypersil-BDS-C8 (Keystone Scientific, Bellefonte, PA, USA) and maintained at $20^{\circ} \mathrm{C}$. Eluent A was water and B was acetonitrile-water (95:5), both containing $2 \mathrm{mM}$ ammonium formate and $50 \mathrm{mM}$ formic acid [50,51]. A linear gradient elution from $20 \%$ to $100 \%$ B was performed over $10 \mathrm{~min}$ and then held at $100 \% \mathrm{~B}$ for $15 \mathrm{~min}$, followed by re-equilibration with $20 \%$ $\mathrm{B}$ (13 min). The flow rate was $0.2 \mathrm{~mL} / \mathrm{min}$ and the injection volume was $10 \mu \mathrm{L}$. MRM LC/MS/MS analysis for the targeted toxins were carried out using the following ions; $[\mathrm{M}-\mathrm{H}]^{-}$(OA, DTX1, 7-O-palmitoyl-DTX1, DTX2, PTX6, PTX2sa, YTX, 45OHYTX) and $[\mathrm{M}+\mathrm{HCOOH}-\mathrm{H}]^{-}$(PTX1, PTX2, PTX11) as the target parent ions in Q1 and particular fragment ions of each toxin in Q3 as reported in a previous study [40]. SIM LC/MS analysis for toxins were carried out using the $\left[\mathrm{M}+\mathrm{NH}_{4}\right]^{+}(\mathrm{OA}, \mathrm{DTX} 1$, DTX2, PTX1, PTX2, PTX6, PTX11) as the target ions in Q1.

Supplementary Materials: The following are available online at http:/ / www.mdpi.com/2072-6651/10/11/457/ s1, Table S1: Toxin profiles of Dinophysis species collected from around the coast of Japan.

Author Contributions: H.U. and T.S. performed sample analysis by LC/MS/MS. S.N., T.K., K.B., A.M., Y.K., S.K., and Y.M. performed sampling and cleanup of sample for LC/MS/MS. R.W., R.M., and H.O. contributed on experimental design, providing several assistances in laboratory facilities for LC/MS analyses. H.U. and T.S. performed data evaluation, important discussion, paper writing as well as experimental design.

Funding: This research was partly conducted by a research project for marine toxin safety measures funded by Japanese Ministry of Agriculture, Forestry, and Fisheries.

Acknowledgments: The authors deeply appreciate Tim Harwood for his kind help for corrections of our English manuscript.

Conflicts of Interest: The authors declare no conflict of interest.

\section{References}

1. Yasumoto, T.; Murata, M. Marine Toxins. Chem. Rev. 1993, 93, 1897-1909. [CrossRef]

2. Yasumoto, T.; Oshima, Y.; Sugawara, W.; Fukuyo, Y.; Oguri, H.; Igarashi, T.; Fujita, N. Identification of Dinophysis fortii as the causative organism of diarrhetic shellfish poisoning. Bull. Jpn. Soc. Fish. 1980, 46, 1405-1411. [CrossRef]

3. FAO and WHO. Standard for Live and Raw Bivalve Molluscs. Codex Stan 292-2008. 2008, pp. 1-9. Available online: http:/ / www.fao.org/fao-who-codexalimentarius/codex-texts/list-standards/en/ (accessed on 5 November 2018).

4. Scientific Opinion of the Panel on Contaminants in the Food Chain. Marine biotoxins in shellfish-Summary on regulated marine biotoxins. EFSA J. 2009, 1306, 1-23.

5. Draisci, R.; Lucentini, L.; Giannetti, L.; Boria, P.; Poletti, R. First report of pectenotoxin-2 (PTX-2) in algae (Dinophysis fortii) related to seafood poisoning in Europe. Toxicon 1996, 34, 923-935. [CrossRef]

6. Suzuki, T.; Mitsuya, T.; Imai, M.; Yamasaki, M. DSP toxin contents in Dinophysis fortii and scallops collected at Mutsu Bay, Japan. J. Appl. Phycol. 1997, 8, 509-515. [CrossRef]

7. James, K.J.; Bishop, A.G.; Healy, B.M.; Roden, C.; Sherlock, I.R.; Twohig, M.; Draisci, R.; Giannetti, L.; Lucentini, L. Efficient isolation of the rare diarrhoeic shellfish toxin, dinophysistoxin-2, from marine phytoplankton. Toxicon 1999, 37, 343-357. [CrossRef] 
8. Suzuki, T.; Walter, J.A.; LeBlanc, P.; MacKinnon, S.; Miles, C.O.; Wilkins, A.L.; Munday, R.; Beuzenberg, V.; MacKenzie, A.L.; Jensen, D.J.; et al. Identification of pectenotoxin-11 as 34 S-hydroxypectenotoxin-2, a new pectenotoxin analogue in the toxic dinoflagellate Dinophysis acuta from New Zealand. Chem. Res. Toxicol. 2006, 19, 310-318. [CrossRef] [PubMed]

9. Pizarro, G.; Paz, B.; Franco, J.M.; Suzuki, T.; Reguera, B. First detection of Pectenotoxin-11 and confirmation of OA-D8 diol-ester in Dinophysis acuta from European waters by LC-MS/MS. Toxicon 2008, 52, 889-896. [CrossRef] [PubMed]

10. Kamiyama, T.; Suzuki, T. Production of dinophysistoxin-1 and pectenotoxin-2 by a culture of Dinophysis acuminata (Dinophyceae). Harmful Algae 2009, 8, 312-317. [CrossRef]

11. Morton, S.L.; Vershinin, A.; Smith, L.L.; Leighfield, T.A.; Pankov, S.; Quilliam, M.A. Seasonality of Dinophysis spp. and Prorocentrum lima in Black Sea phytoplankton and associated shellfish toxicity. Harmful Algae 2009, 8, 629-636. [CrossRef]

12. Fux, E.; Smith, J.L.; Tong, M.; Guzman, L.; Anderson, D.M. Toxin profiles of five geographical isolates of Dinophysis spp. from North and South America. Toxicon 2011, 57, 275-287. [CrossRef] [PubMed]

13. Nagai, S.; Suzuki, T.; Nishikawa, T.; Kamiyama, T. Differences in the production and excretion kinetics of okadaicacid, dinophysistoxin-1, and pectenotoxin-2 between cultures of Dinophysis acuminata and Dinophysis fortii isolated from western japan. J. Phycol. 2011, 47, 1326-1337. [CrossRef] [PubMed]

14. Nagai, S.; Suzuki, T.; Kamiyama, T. Successful cultivation of the toxic dinoflagellate Dinophysis tripos (Dinophyceae). Plankton Benthos Res. 2013, 8, 171-177. [CrossRef]

15. Blanco, E.P.; Karlsson, C.; Pallon, J.; Yasumoto, T.; Granéli, E. Cellular nutrient content measured with the nuclear microprobe and toxins produced by Dinophysis norvegica (Dinophyceae) from the Trondheim fjord (Norway). Aquat. Microb. Ecol. 2015, 75, 259-269. [CrossRef]

16. Mafra, L.L., Jr.; Lopes, D.; Bonilauri, V.C.; Uchida, H.; Suzuki, T. Persistent contamination of octopuses and mussels with lipophilic shellfish toxins during spring Dinophysis blooms in a subtropical estuary. Mar. Drugs 2015, 13, 3920-3935. [CrossRef] [PubMed]

17. Basti, L.; Uchida, H.; Matsushima, R.; Watanabe, R.; Suzuki, T.; Yamatogi, T.; Nagai, S. Influence of Temperature on Growth and Production of Pectenotoxin-2 by a Monoclonal Culture of Dinophysis caudata. Mar. Drugs 2015, 13, 7124-7137. [CrossRef] [PubMed]

18. Nielsen, L.T.; Hansen, P.J.; Krock, B.; Vismann, B. Accumulation, transformation and breakdown of DSP toxins from the toxic dinoflagellate Dinophysis acuta in blue mussels, Mytilus edulis. Toxicon 2016, 117, 84-93. [CrossRef] [PubMed]

19. Lee, J.S.; Igarashi, T.; Santiago, F.; Einal, D.; Peter, H.; Yasumoto, T. Determination of diarrhetic shellfish toxins in various dinoflagellate species. J. Appl. Phycol. 1989, 1, 147-152. [CrossRef]

20. Johansson, N.; Graneli, E.; Yasumoto, T.; Carlsson, P.; Legrand, C. Toxin production by Dinophysis acuminata and D. acuta cells grown under nutrient sufficient and deficient conditions. In Harmful and Toxic Algal Bloom; Yasumoto, T., Oshima, Y., Fukuyo, Y., Eds.; Intergovernmental Oceanographic Comission of UNESCO: Sendai, Japan, 1996; pp. 277-280.

21. Fernández, M.L.; Reguera, B.; Ramilo, I.; Martínez, A. Toxin content of Dinophysis acuminata, D. acuta, D. caudata from the Galician Rias Bajas. In Harmful and Toxic Algal Bloom; Hallegraeff, G.M., Blackburn, S.I., Bolch, C.J., Lewis, R.J., Eds.; Intergovernmental Oceanographic Comission of UNESCO: Hobart, Tasmania, Australia, 2001; pp. 360-363.

22. Blanco, J.; Álvarez, G.; Uribe, E. Identification of pectenotoxins in plankton, filter feeders, and isolated cells of a Dinophysis acuminata with an atypical toxin profile, from Chile. Toxicon 2007, 49, 710-716. [CrossRef] [PubMed]

23. Suzuki, T.; Miyazono, A.; Baba, K.; Sugawara, R.; Kamiyama, T. LC-MS/MS analysis of okadaic acid analogues and other lipophilic toxins in single-cell isolates of several Dinophysis species collected in Hokkaido, Japan. Harmful Algae 2009, 8, 233-238. [CrossRef]

24. Miles, C.O.; Wilkins, A.L.; Samdal, I.A.; Sandvik, M.; Petersen, D.; Quilliam, M.A.; Naustvoll, L.J.; Rundberget, T.; Torgersen, T.; Hovgaard, P.; et al. A novel pectenotoxin, PTX-12, in Dinophysis spp. and shellfish from Norway. Chem. Res. Toxicol. 2004, 17, 1423-1433. [CrossRef] [PubMed]

25. Pizarro, G.; Moroño, A.; Paz, B.; Franco, J.M.; Pazos, Y.; Reguera, B. Evaluation of Passive Samplers as a Monitoring Tool for Early Warning of Dinophysis Toxins in Shellfish. Mar. Drugs 2013, 11, 3823-3845. [CrossRef] [PubMed] 
26. Sato, S.; Koike, K.; Kodama, M. Seasonal variation of okadaic acid and dinophysistoxin-1 in Dinophysis spp. in association with the toxicity of scallop. In Harmful and Toxic Algal Bloom; Yasumoto, T., Oshima, Y., Fukuyo, Y., Eds.; Intergovernmental Oceanographic Comission of UNESCO: Sendai, Japan, 1996; pp. $285-288$.

27. James, K.J.; Bishop, A.G.; Gillman, M.; Kelly, S.S.; Roden, C.; Draisci, R.; Lucentini, L.; Giannetti, L. The Diarrhoeic Shellfish Poisoning toxins of Dinophysis acuta: Identification and isolation of dinophysistoxin-2 (DTX-2). In Harmful and Toxic Algal Bloom; Reguera, B., Blanco, J., Fernández, L.M., Wyatt, T., Eds.; Xunta de Galicia and Intergovernmental Oceanographic Comission of UNESCO: Santiago de Compostela, Spain, 1998; pp. 489-492.

28. Puente, P.F.; Sáez, M.J.F.; Hamilton, B.; Furey, A.; James, K.J. Studies of polyether toxins in the marine phytoplankton, Dinophysis acuta, in Ireland using multiple tandem mass spectrometry. Toxicon 2004, 44, 919-926. [CrossRef] [PubMed]

29. Fernández, L.M.; Reguera, B.; González, G.S.; Mguez, A. Pectenotoxin-2 in single-cell isolates of Dinophysis caudata and Dinophysis acuta from the Galician Rías (NW Spain). Toxicon 2006, 48, 477-490. [CrossRef] [PubMed]

30. Pizarro, G.; Paz, B.; González, G.S.; Franco, J.M.; Reguera, B. Seasonal variability of lipophilic toxins during a Dinophysis acuta bloom in Western Iberia: Differences between picked cells and plankton concentrates. Harmful Algae 2009, 8, 233-238. [CrossRef]

31. Marasigan, A.N.; Sato, S.; Fukuyo, Y.; Kodama, M. Accumulation of a high level of diarrhetic shellfish toxins in the green mussel Perna viridis during a bloom of Dinophysis caudata and Dinophysis miles in Sapian Bay, Panay Island, the Philippines. Fish. Sci. 2001, 67, 994-996. [CrossRef]

32. Jiang, T.; Liu, L.; Li, Y.; Zhang, J.; Tan, Z.; Wu, H.; Jiang, T.; Lu, S. Occurrence of marine algal toxins in oyster and phytoplankton samples in Daya Bay, South China Sea. Chemosphere 2017, 183, 80-88. [CrossRef] [PubMed]

33. Raho, N.; Pizarro, G.; Escalera, L.; Reguera, B.; Marin, I. Morphology, toxin composition and molecular analysis of Dinophysis ovum Schütt, a dinoflagellate of the "Dinophysis acuminata complex". Harmful Algae 2008, 7, 839-848. [CrossRef]

34. González, G.S.; Pizarro, G.; Paz, B.; Velo-Suarez, L.; Reguera, B. Considerations on thetoxigenic nature and prey sources of Phalacroma rotundatum. Aquat. Microb. Ecol. 2011, 64, 197-203. [CrossRef]

35. Masselin, P.; Lassus, P.; Bardouil, M. High performance liquid chromatography analysis of diarrhetic toxins in Dinophysis spp. from French coast. J. Appl. Phycol. 1992, 4, 385-389. [CrossRef]

36. Reguera, B.; Riobó, P.; Rodríguez, F.; Díaz, P.A.; Pizarro, G.; Paz, B.; Franco, J.M.; Blanco, J. Dinophysis Toxins: Causative Organisms, Distribution and Fate in Shellfish. Mar. Drugs 2014, 12, 394-461. [CrossRef] [PubMed]

37. Reguera, B.; Pizarro, G. Planktonic Dinoflagellates That Contain Polyether Toxins of the Old "DSP Complex". In Seefood and Freshwater Toxins, Pharmacology, Physiology, and Detection, 2nd ed.; Luis, M.B., Ed.; CRC Press, Taylor and Francis Group: New York, NY, USA, 2008; pp. 258-276.

38. Suzuki, T.; Quilliam, M.A. LC-MS/MS Analysis of Diarrhetic Shellfish Poisoning (DSP) Toxins, Okadaic Acid and Dinophysistoxin Analogues, and Other Lipophilic Toxins. Anal. Sci. 2011, 27, 572-584. [CrossRef]

39. MacKenzie, A.L.; Beuzenberg, V.; Holland, P.; McNabb, P.; Suzuki, T.; Selwood, A. Pectenotoxin and okadaic acid-based toxin profiles in Dinophysis acuta and Dinophysis acuminata from New Zealand. Harmful Algae 2005, 4, 75-85. [CrossRef]

40. MacKenzie, A.L.; Beuzenberg, V.; Holland, P.; McNabb, P.; Selwood, A. Solid phase adsorption toxin tracking (SPATT): A new monitoring tool that simulates the biotoxin contamination of filter feeding bivalves. Toxicon 2004, 44, 901-918. [CrossRef] [PubMed]

41. Ministry of Agriculture, Forestry and Fisheries. Guidelines for Risk Management of Shellfish Toxins in Bivalves. 2015. Available online: http://www.maff.go.jp/j/syouan/tikusui/gyokai/g_kenko/busitu/pdf/ 150306_kaidoku_guide.pdf (accessed on 5 November 2018).

42. Yasumoto, T.; Oshima, Y.; Yamaguchi, M. Occurrence of a New Type of shellfish poisoning in the Tohoku district. Bull. Jpn. Soc. Fish. 1978, 44, 1249-1255. [CrossRef]

43. Sato, N.; Ishige, M.; Kawase, S.; Tazawa, T.; Nakagawa, T. First cases of Paralytic and Diarrhoetic shellfish poisoning in Hokkaido. Rep. Hokkaido Inst. Public Health 1983, 33, 78-83.

44. Toda, M.; Uneyama, C.; Toyofuku, H.; Morikawa, K. Trends of Food Poisonings Caused by Natural Toxins in Japan, 1989-2011. J. Food Hyg. Soc. Jpn. 2011, 53, 105-119. [CrossRef] 
45. Suzuki, T.; Jin, T.; Shirota, Y.; Mitsuya, T.; Okumura, Y.; Kamiyama, T. Quantification of lipophilic toxins associated with diarrhetic shellfish poisoning in Japanese bivalves by liquid chromatography-mass spectrometry and comparison with mouse bioassay. Fish. Sci. 2005, 71, 1370-1378. [CrossRef]

46. Suzuki, T.; Kamiyama, T.; Okumura, Y.; Ishihara, K.; Matsushima, R.; Kaneniwa, M. Liquid-chromatographic hybrid triple-quadrupole linear-ion-trap MS/MS analysis of fatty-acid esters of dinophysistoxin-1 in bivalves and toxic dinoflagellates in Japan. Fish. Sci. 2009, 75, 1039-1048. [CrossRef]

47. Japanese Ministry of Health and Welfare. Food Sanitation Research; Japanese Ministry of Health and Welfare: Toyko, Japan, 1981; Volume 7, p. 60.

48. Suzuki, T.; Mitsuya, T.; Matsubara, H.; Yamasaki, M. Determination of pectenotoxin-2 after solid-phase extraction from seawater and from the dinoflagellate Dinophysis fortii by liquid chromatography with electrospray mass spectrometry and ultraviolet detection Evidence of oxidation of pectenotoxin-2 to pectenotoxin-6 in scallops. J. Chromatogr. A 1998, 815, 155-160. [PubMed]

49. Goto, H.; Igarashi, T.; Sekiguchi, R.; Tanno, K.; Satake, M.; Oshima, Y.; Yasumoto, T. A Japanese project for production and distribution of shellfish toxins as calibrants for HPLC analysis. In Proc. VIII International Conference on Harmful Algae; Reguera, B., Blanco, J., Fernández, M.L., Wyatt, T., Eds.; Xunta de Galicia and Intergovernmental Oceanographic Commission of UNESCO: Vigo, Spain, 1998; pp. 216-219.

50. Quilliam, M.A.; Hess, P.; Dell'Aversano, C. Recent developments in the analysis of phycotoxins by liquid chromatography-mass spectrometry. In Perspective at the Turn of the Millenium, Proceedings of the 10th International IUPAC Symposium on Mycotoxins and Phycotoxins, Guaruja, Brazil, 21-25 May 2000; De Koe, W.J., Samson, R.A., van Egmond, H.P., Gilbert, J., Sabino, M., Eds.; IRIS: Guaruja, Brazil, 2001; pp. 383-391.

51. Quilliam, M.A. The role of chromatography in the hunt for red tide toxins. J. Chromatogr. A 2003, 1000, 527-548. [CrossRef]

(C) 2018 by the authors. Licensee MDPI, Basel, Switzerland. This article is an open access article distributed under the terms and conditions of the Creative Commons Attribution (CC BY) license (http:/ / creativecommons.org/licenses/by/4.0/). 